\title{
Field evaluation of a plant activator, captan, chlorothalonil, copper hydroxide, iprodione, mancozeb and strobilurins for the control of citrus brown spot of mandarin
}

\author{
A. K. Miles ${ }^{\mathrm{A}, \mathrm{B}}$, S. L. Willingham ${ }^{\mathrm{A}}$ and A. W. Cooke \\ ${ }^{\text {A } H o r t i c u l t u r e, ~ D e p a r t m e n t ~ o f ~ P r i m a r y ~ I n d u s t r i e s, ~} 80$ Meiers Road, Indooroopilly, Qld 4068, Australia. \\ ${ }^{\mathrm{B}}$ Corresponding author. Email: andrew.miles@dpi.qld.gov.au
}

\begin{abstract}
Brown spot (caused by Alternaria alternata) is a major disease of citrus in subtropical areas of Australia. A number of chemicals, the strobilurins azoxystrobin, trifloxystrobin, pyraclostrobin and methoxycrylate, a plant activator (acibenzolar), copper hydroxide, mancozeb, captan, iprodione and chlorothalonil/pyrimthanil were tested in the field for its control. Over three seasons, trees in a commercial orchard received 16, 14 and 7 fungicide sprays, respectively, commencing at flowering in the first season, and petal fall in the later seasons. In all experiments, the strobilurins used alone, or incorporated with copper and mancozeb, were as effective as, or better than the industry standard of copper and mancozeb alone. The only exception was trifloxystrobin, which when used alone was less effective than the industry standard. Acibenzolar used alone was ineffective. Applying a mixture of azoxystrobin and acibenzolar was found to reduce the incidence of brown spot compared with applying azoxystrobin alone but, in either case, disease levels were not found to be significantly different to the industry standard. Captan, iprodione and chlorothalonil/pyrimthanil were as effective as the industry standard. The incidence and severity of rind damage were significantly lowest in the azoxystrobin, methoxycrylate, iprodione and chlorothalonil/pyrimthanil treatments. Medium and high rates of trifloxystrobin $(0.07 \mathrm{~g} / \mathrm{L}, 0.15 \mathrm{~g} / \mathrm{L})$ and pyraclostrobin $(0.8 \mathrm{~g} / \mathrm{L}, 1.2 \mathrm{~g} / \mathrm{L})$ applied alone were the only treatments found to be IPM-incompatible as shown by the elevated level of scale infection on fruit.
\end{abstract}

Additional keywords: integrated pest management, mandarin, orange, induced resistance.

\section{Introduction}

Brown spot of mandarins, caused by the necrotrophic fungus Alternaria alternata is a major disease in many citrus-growing regions of the world, including Australia, Israel, South Africa and the USA (Solel et al. 1997; Swart et al. 1998; Timmer et al. 1998). In Australia, the disease was first recorded on mandarin cv. Emperor in 1903 (Cobb 1903), and is considered to be of particular importance in coastal regions of southeast Queensland, but can also affect orchards in the central Burnett and Bundaberg districts, as well as some northern coastal New South Wales regions. Symptoms of brown spot are small, round, black or brown, necrotic lesions surrounded by a chlorotic halo on fruit, young leaves and/or twigs. In severe cases, large necrotic areas are found, vein darkening can occur, infected leaves and fruit can prematurely senesce, and entire shoot death can occur (Pegg 1966; Swart et al. 1998, Timmer et al. 2000). Brown, sunken, lesions are typically found on infected fruit, and reach up to $5 \mathrm{~mm}$ in diameter (Persley 1993). These symptoms reduce the value of harvested fruit, and overall tree performance (Solel et al. 1997). Leaves are susceptible to the disease until they are fully expanded and hardened, while fruit are susceptible until they reach approximately $5 \mathrm{~cm}$ in diameter (Timmer et al. 2000). The experience of citrus growers in Queensland, however, is that fruit of mandarin cv. Murcott are never resistant to brown spot, but no scientific data confirming this have been generated. Lesions caused by A. alternata are a result of the production of a host-specific toxin (HST) by the fungus (Kohmoto et al. 1991). The HST produced by the tangerine pathotype of $A$. alternata has compounds similar to other Alternaria toxins that have been shown to cause cell wall breakdown correlated with $\mathrm{K}^{+}$efflux (Nishimura and Kohmoto 1983). The ultimate result is cell death and lesion formation in the host tissues. As a consequence, the control of brown spot depends on the use of protectant fungicides, rather than eradicants that cannot reverse cell necrosis.

Brown spot affects tangerine $\times$ grapefruit and tangerine $\times$ sweet orange hybrids (Solel et al. 1997). 
Of particular importance in Queensland is the tangerine hybrid cv. Murcott, which produced 24700 tonnes in 2000, representing approximately $20 \%$ of Australia's mandarin production. The disease first reached epidemic proportions in Queensland in 1982 after an extended wet period in autumn (Hutton and Mayers 1988).

Control of brown spot greatly relies on the continual application of mancozeb and copper-based protectant fungicides when conditions are favourable for the pathogen (Solel et al. 1997; Swart et al. 1998; Timmer et al. 2000). However, use of these products causes undesirable side effects. For example, copper-based fungicides can reach toxic levels in soil and plants, and have been reported to cause rind stippling and darkening of pre-existing blemishes (Schutte et al. 1997; Timmer et al. 1998; Agostini et al. 2003). In addition, mancozeb is highly toxic to the predatory mite Amblyseius victoriensis, an important species of the integrated pest management (IPM) system widely used in citrus for control of the mite pests brown citrus rust mite (Tegolophus australis) and broad mite (Phyllocoptruta oleivora) (Smith and Papacek 1991). Fungicide treatments incorporating mancozeb greatly reduce populations of Amblyseius victoriensis on mandarin cv. Nova, as well as increase rind damage (Miles et al. 2004).

This paper reports three field experiments over three consecutive seasons where we evaluated strobilurin fungicides and the plant activator, acibenzolar. The strobilurin fungicides are synthetic analogues of naturally occurring fungitoxic metabolites produced by the edible mushroom Stobilurus tenacellus (Godwin et al. 1994). The strobilurins inhibit respiration of fungal mitochondria (Becker et al. 1981). The result is a severe reduction in aerobic energy production by fungi and inhibition of growth (Godwin et al. 1994). Perhaps the greatest advantages of the strobilurin fungicides are low mammalian toxicity (Sauter et al. 1996) and low toxicity to the indigenous predator Euseius victoriensis used in IPM (M. B. Bernard, personal communication).

The plant activator acibenzolar (Bion) is a non-fungicidal compound that can be used to combat plant pathogens by inducing the host plant's natural defence mechanisms (Tally et al. 1999). This chemical is a functional analogue of salicylic acid (SA), shown to accumulate in plants challenged with a pathogen (Friedrich et al. 1996). Following accumulation of SA, plant defence genes are induced (Lawton et al. 1996), triggering the production of defence compounds.

Compatibility with IPM is an important consideration when screening new products for disease control in citrus. In the following experiments, the effect of chemical treatments on scale insect severity and incidence was recorded. Numerous predatory wasp species are involved in controlling scale pests and extensive measures have been taken by the citrus industry to promote these predatory insects for control of scale pests, so it is important that chemicals used for disease control are not toxic to predators. For the purposes of this study, scale levels on fruit treated with the various chemicals were used as an indicator of IPM compatibility.

\section{Methods}

The products described in Table 1 were applied in field experiments on commercial citrus orchards in Queensland, Australia. In all experiments, the chemicals were applied to individual trees until drip-off ( $\sim 10-25 \mathrm{~L}$ per tree) using a Hardi hand-held lance fitted with dual hollow cone operating at $\sim 60 \mathrm{psi}$ of pressure.

Table 1. Product names, active ingredients, manufacturers and standard rates of chemicals used in citrus brown spot chemical control experiments carried out in Queensland, Australia

\begin{tabular}{|c|c|c|c|}
\hline Product name & Active ingredient & Manufacturer $^{\mathrm{A}}$ & $\begin{array}{l}\text { Standard rate of } \\
\text { product }(x)^{\mathrm{B}}\end{array}$ \\
\hline Amistar & $50 \%$ azoxystrobin & Syngenta & $0.4 \mathrm{~g} / \mathrm{L}$ \\
\hline Bion & $50 \%$ acibenzolar & Syngenta & $0.05 \mathrm{~g} / \mathrm{L}$ \\
\hline Captan WG & $80 \%$ captan & Crop Care & $1.25 \mathrm{~g} / \mathrm{L}$ \\
\hline DC Tron & $78.2 \%$ petroleum oil & Caltex & $6.00 \mathrm{~mL} / \mathrm{L}$ \\
\hline Flint & $50 \%$ trifloxystrobin & Bayer & $0.07 \mathrm{~g} / \mathrm{L}$ \\
\hline HEC 5725 & methoxycrylate & Bayer & $1.60 \mathrm{~mL} / \mathrm{L}$ \\
\hline Headline & $23.6 \%$ pyraclostrobin & BASF & $0.80 \mathrm{~g} / \mathrm{L}$ \\
\hline Kocide & $40 \%$ copper hydroxide & Griffin & $2.00 \mathrm{~g} / \mathrm{L}$ \\
\hline Mancozeb DF & $75 \%$ mancozeb & Crop Care & $2.00 \mathrm{~g} / \mathrm{L}$ \\
\hline Rovral Aquaflo & $50 \%$ iprodione & Bayer & $1.00 \mathrm{~mL} / \mathrm{L}$ \\
\hline Walabi & $\begin{array}{c}70 \% \text { chlorothalonil/ } \\
30 \% \text { pyrimthanil }\end{array}$ & Bayer & $2.0 \mathrm{~mL} / \mathrm{L}$ \\
\hline
\end{tabular}

\footnotetext{
A Addresses of manufacturers are: Syngenta - PO Box 249, Wentworthville, NSW 2145, Australia; Crop Care - PO Box 167, Hamilton Central, Qld 4007, Australia; Caltex - GPO Box 3916, Sydney, NSW 2000, Australia; Bayer - PO Box 903, Pymble, NSW 2073, Australia; BASF — PO Box 7026, Baulkham Hills, NSW 2153, Australia; Griffin - 168 Walker Street, North Sydney, NSW 2060, Australia.

${ }^{\mathrm{B}}$ Rate used throughout all experiments except where otherwise specified as a factor of ' $x$ '.
} 


\section{Experiment 1}

In the 2000-01 cropping season a commercial citrus orchard near Tiaro, Queensland $\left(\mathrm{S} 25^{\circ} 44^{\prime}, \mathrm{N} 152^{\circ} 35^{\prime}\right)$, known to have a high incidence of brown spot, was selected for this experiment. Six-year-old Murcott mandarin trees on cv. Troyer rootstock were treated with the following chemical programs, each with a total of 16 sprays per treatment, commencing at flowering and continuing every 3-4 weeks, stopping 7 days before harvest; untreated control (no sprays), industry standard $(2 \times$ Kocide + DC Tron, $14 \times$ Mancozeb DF), azoxystrobin $(16 \times$ Amistar), methoxycrylate $(16 \times$ HEC 5725), iprodione + mancozeb $(16 \times$ Rovral Aquaflo + Mancozeb DF $)$, chlorothalonil/pyrimthanil $(16 \times$ Walabi), each of these treatments were tank mixed with acibenzolar e.g. azoxystrobin + acibenzolar $(16 \times$ Amistar + Bion $)$, and azibenzolar was used alone $(16 \times$ Bion $)$, giving a total of 12 treatments.

\section{Experiment 2}

This experiment in the 2001-02 cropping season used the same commercial citrus orchard and block as in Experiment 1, but different trees were selected. The following chemical programs, each with a total of 14 sprays per treatment, commencing at $1 / 4$ petal fall and continuing every 3-4 weeks, ceasing 16 days before harvest; untreated control (no chemicals), industry standard $(1 \times 0.5 x \mathrm{~g} / \mathrm{L}$ Kocide + DC Tron, $12 \times$ Mancozeb DF commencing at $3 / 4$ petal fall), azoxystrobin $[0.5 x]$ $(14 \times 0.5 x \mathrm{~g} / \mathrm{L}$ Amistar $)$, azoxystrobin $[x](14 \times$ Amistar $)$, azoxystrobin [1.5x] $(14 \times 1.5 x \mathrm{~g} / \mathrm{L}$ Amistar $)$, trifloxystrobin $[0.5 x](14 \times 0.5 x \mathrm{~g} / \mathrm{L}$ Flint $)$, trifloxystrobin $[x](14 \times$ Flint $)$, trifloxystrobin $[2 x](14 \times 2 x \mathrm{~g} / \mathrm{L}$ Flint), azoxystrobin $[0.5 x]$ anti-resistance $(1 \times 0.5 x \mathrm{~g} / \mathrm{L}$ Kocide + DC Tron, $2 \times 0.5 \times \mathrm{g} / \mathrm{L}$ Amistar, $10 \times$ Mancozeb $\mathrm{DF}$ commencing at $3 / 4$ petal fall), azoxystrobin $[x]$ anti-resistance $(1 \times 0.5 x \mathrm{~g} / \mathrm{L}$ Kocide + DC Tron, $2 \times$ Amistar, $10 \times$ Mancozeb DF commencing at $3 / 4$ petal fall), trifloxystrobin $[x]$ anti-resistance $(1 \times 0.5 x \mathrm{~g} / \mathrm{L}$ Kocide + DC Tron, $2 \times$ Flint, $10 \times$ Mancozeb DF commencing at $3 / 4$ petal fall $)$, and trifloxystrobin $[2 x]$ anti-resistance $(1 \times 0.5 x \mathrm{~g} / \mathrm{L}$ Kocide + DC Tron, $2 \times 2 x \mathrm{~g} / \mathrm{L}$ Flint, $10 \times$ Mancozeb DF commencing at $3 / 4$ petal fall) giving a total of 12 treatments.

\section{Experiment 3}

This experiment was conducted during the 2002-03 cropping season in a commercial citrus orchard near Tiaro, Queensland $\left(\mathrm{S} 25^{\circ} 44^{\prime}, \mathrm{N} 152^{\circ} 35^{\prime}\right)$, known to have a high incidence of brown spot. Seven-year-old cv. Nova mandarin trees on cv. Troyer rootstocks were treated with the following chemical programs, each with a total of seven sprays, commencing 40 days after petal fall and continuing every 3-4 weeks, ceasing 30 days before harvest; untreated control (no chemicals), industry standard $(7 \times$ Mancozeb DF), azoxystrobin $[0.5 x]$ anti-resistance $(2 \times 0.5 x \mathrm{~g} / \mathrm{L}$ Amistar, $2 \times$ Mancozeb DF, $1 \times 0.5 x \mathrm{~g} / \mathrm{L}$ Amistar, $2 \times$ Mancozeb DF), azoxystrobin $[x]$ anti-resistance $(2 \times$ Amistar, $2 \times$ Mancozeb DF, $1 \times$ Amistar, $2 \times$ Mancozeb DF), pyraclostrobin [0.5x] anti-resistance $(2 \times 0.5 x \mathrm{~g} / \mathrm{L}$ Headline, $2 \times$ Mancozeb DF, $1 \mathrm{v} 0.5 x \mathrm{~g} / \mathrm{L}$ Headline, $2 \times$ Mancozeb DF), pyraclostrobin $[x]$ anti-resistance $(2 \times$ Headline, $2 \times$ Mancozeb DF, $1 \times$ Headline, $2 \times$ Mancozeb DF), pyraclostrobin $[0.5 x](7 \times 0.5 x \mathrm{~g} / \mathrm{L}$ Headline $)$, pyraclostrobin $[x](7 \times$ Headline $)$, pyraclostrobin $[1.5 x](7 \times 0.5 x \mathrm{~g} / \mathrm{L}$ Headline $)$, and captan $(7 \times$ Captan WG) giving a total of ten treatments. All treatments received two extra fungicide treatments applied commercially using an oscillating boom prior to implementation of the experimental treatments: copper hydroxide (Kocide $200 \mathrm{~g} / \mathrm{L}$ ) tank mixed with zinc sulphate $(100 \mathrm{~g} / \mathrm{L})$, magnesium sulphate $(100 \mathrm{~g} / \mathrm{L})$ and oil (DC Tron at $6 \mathrm{~mL} / \mathrm{L})$ at petal fall $(01 / 10 / 02)$, and Mancozeb DF (200 g/L) 4 weeks (22/10/02) after the first spray.

In all experiments, a split-plot with four single-tree replicates per treatment was used. Whole plots were split for fruit position, where one carton of mature fruit ( $\sim 60$ fruit) was picked randomly from each of the eastern and western sides of the tree at commercial harvest time (experiment 1, 19/07/2001; experiment 2, 31/7/2002; experiment 3, $6 / 05 / 2003$ ). Fruit were placed at $22^{\circ} \mathrm{C}$ for 3 weeks before the severity of brown spot and rind damage were visually assessed. Incidence of brown spot was recorded (percentage of affected fruit), and severity rated using a $1-4$ severity scale (Experiment 1 , where $1=$ no disease, $2=1-25 \%, 3=26-50 \%, 4=51-100 \%$ of the fruit surface affected, and as individual lesion counts for experiments 2 and 3 ). Rind damage was assessed as any form of physical injury to the fruit rind (wind blemish, insect damage etc.) and was measured in experiment 1 only, as incidence (percentage of affected fruit) and using a severity scale of $1-4$, where $1=$ no damage, $2=1-25 \%, 3=26-50 \%, 4=51-100 \%$ of the fruit surface affected. The severity of scale infestation was visually assessed in experiments 2 and 3. Scale results are presented as severity (on a scale of $1-4$, where $1=$ no scale, $2=1-25 \%$, $3=26-50 \%, 4=51-100 \%$ of the fruit surface affected) and incidence (percentage of affected fruit).

\section{Statistical analysis}

Statistical analyses were conducted using Genstat 5 release 4.1 data analysis software (Lawes Agricultural Trust, Rothamsted Experimental Station) for a split-plot design with whole plots split for fruit position. Arcsine angular transformations were made on percentage data and square root transformations were made on severity data. However, examination of residual plots indicated transformations did not show improved distribution of residuals. Hence, untransformed data are presented. Pair-wise testing between means was done using the least significant difference (LSD) procedure at $P=0.05$.

\section{Results}

\section{Experiment 1}

On average, the incidence and severity of brown spot were significantly reduced by $\sim 80 \%$ and $55 \%$, respectively by all the fungicide treatments compared with the untreated control (Table 2). The incidence and severity of brown spot when acibenzolar was used alone were not significantly different from the untreated control (Table 2). All the fungicide treatments were as effective at controlling brown spot as the industry standard treatment (Table 2). Tank mixing acibenzolar with azoxystrobin significantly improved disease control compared with azoxystrobin alone ( $>50 \%$ improvement), but neither of these two treatments was significantly different from the industry standard (Table 2).

The incidence and severity of rind damage in the untreated control, industry standard, acibenzolar, and industry standard + acibenzolar treatments were significantly higher than all the other treatments (Table 2). Adding acibenzolar to the industry standard fungicides significantly increased the severity of rind damage by $\sim 15 \%$ (Table 2 ). Tank mixing acibenzolar with the other fungicides did not significantly affect rind damage (Table 2). Fruit aspect did not significantly affect brown spot, but fruit harvested from the eastern aspect of the tree had a significantly higher incidence, and greater severity, of rind damage (Table 2). 
Table 2. Experiment 1 (2000-2001): effects of chemicals and canopy aspect on the incidence and severity of citrus brown spot (caused by Alternaria alternata) and rind damage of cv. Murcott mandarin fruit $^{\mathrm{A}}$

\begin{tabular}{|c|c|c|c|c|}
\hline \multirow[t]{2}{*}{ Treatment } & \multicolumn{2}{|c|}{ Citrus brown spot } & \multicolumn{2}{|c|}{ Rind damage } \\
\hline & Incidence $^{\mathrm{B}}(\%)$ & Severity $^{\mathrm{C}}(1-4)$ & Incidence $^{\mathrm{B}}(\%)$ & Severity $^{\mathrm{C}}(1-4)$ \\
\hline Untreated control & $92.2 \mathrm{a}$ & $2.8 \mathrm{a}$ & $86.1 \mathrm{a}$ & $2.2 \mathrm{ab}$ \\
\hline Industry standard ${ }^{\mathrm{D}}$ & 19.6 bcde & $1.2 \mathrm{~b}$ & $85.8 \mathrm{a}$ & $2.3 \mathrm{ab}$ \\
\hline Acibenzolar $0.05 \mathrm{~g} / \mathrm{L}$ & $84.0 \mathrm{a}$ & $2.5 \mathrm{a}$ & $71.0 \mathrm{a}$ & $2.0 \mathrm{~b}$ \\
\hline Industry standard + acibenzolar $0.05 \mathrm{~g} / \mathrm{L}$ & 10.9 cde & $1.1 \mathrm{~b}$ & $86.6 \mathrm{a}$ & $2.3 \mathrm{a}$ \\
\hline Azoxystrobin $0.4 \mathrm{~g} / \mathrm{L}$ & $25.7 \mathrm{bc}$ & $1.3 \mathrm{~b}$ & $39.1 \mathrm{bc}$ & $1.4 \mathrm{~cd}$ \\
\hline Azoxystrobin $0.4 \mathrm{~g} / \mathrm{L}+$ acibenzolar $0.05 \mathrm{~g} / \mathrm{L}$ & $9.4 \mathrm{de}$ & $1.1 \mathrm{~b}$ & 39.9 bc & $1.4 \mathrm{~cd}$ \\
\hline Methoxycrylate $1.6 \mathrm{~mL} / \mathrm{L}$ & $31.3 \mathrm{~b}$ & $1.3 \mathrm{~b}$ & $53.3 \mathrm{~b}$ & $1.6 \mathrm{c}$ \\
\hline Methoxycrylate $1.6 \mathrm{~mL} / \mathrm{L}+$ acibenzolar $0.05 \mathrm{~g} / \mathrm{L}$ & $24.7 \mathrm{bcd}$ & $1.3 \mathrm{~b}$ & $36.0 \mathrm{bc}$ & $1.4 \mathrm{~cd}$ \\
\hline Iprodione $1 \mathrm{~mL} / \mathrm{L}+$ mancozeb $2 \mathrm{~g} / \mathrm{L}$ & 11.4 cde & $1.1 \mathrm{~b}$ & $23.4 \mathrm{c}$ & $1.3 \mathrm{~d}$ \\
\hline $\begin{array}{l}\text { Iprodione } 1 \mathrm{~mL} / \mathrm{L}+\text { mancozeb } \\
2 \mathrm{~g} / \mathrm{L}+\text { acibenzolar } 0.05 \mathrm{~g} / \mathrm{L}\end{array}$ & $6.3 \mathrm{e}$ & $1.1 \mathrm{~b}$ & $36.6 \mathrm{bc}$ & $1.4 \mathrm{~cd}$ \\
\hline Chlorothalonil / pyrimthanil $2 \mathrm{~mL} / \mathrm{L}$ & $15.3 \mathrm{cde}$ & $1.2 \mathrm{~b}$ & $40.7 \mathrm{bc}$ & $1.6 \mathrm{c}$ \\
\hline $\begin{array}{l}\text { Chlorothalonil / pyrimthanil } \\
22 \mathrm{~mL} / \mathrm{L}+\text { acibenzolar } 0.05 \mathrm{~g} / \mathrm{L}\end{array}$ & 19.2 bcde & $1.2 \mathrm{~b}$ & $46.5 \mathrm{~b}$ & $1.5 \mathrm{~cd}$ \\
\hline $\operatorname{LSD}(P=0.05)$ & 15.3 & 0.4 & 16.2 & 0.3 \\
\hline \multicolumn{5}{|l|}{ Canopy aspect } \\
\hline East & $26.7 \mathrm{a}$ & $1.4 \mathrm{a}$ & $58.9 \mathrm{a}$ & $1.8 \mathrm{a}$ \\
\hline West & $29.8 \mathrm{a}$ & $1.1 \mathrm{a}$ & $48.1 \mathrm{~b}$ & $1.6 \mathrm{~b}$ \\
\hline $\operatorname{LSD}(P=0.05)$ & - & - & 21.31 & 0.1 \\
\hline
\end{tabular}

${ }^{\mathrm{A}}$ Mean values within columns followed by the same letter are not significantly different at $P=0.05(n=4)$.

${ }^{\mathrm{B}}$ Incidence rated as percentage of affected fruit.

${ }^{\mathrm{C}}$ Severity rated on a $1-4$ scale based on a percentage surface area affected where $1=0 \%, 2=1-25 \%, 3=26-50 \% 4=>50 \%$.

${ }^{\mathrm{D}}$ Industry standard program - two applications of copper oxychloride (Kocide at $2 \mathrm{~g} / \mathrm{L}$ ) + Oil (DC Tron at $6 \mathrm{~mL} / \mathrm{L}$ ) followed by 14 applications of mancozeb $(2 \mathrm{~g} / \mathrm{L})+$ Oil (DC Tron at $6 \mathrm{~mL} / \mathrm{L})$.

\section{Experiment 2}

All the fungicide treatments significantly reduced the incidence and severity of brown spot compared with the untreated control by at least $65 \%$ and $90 \%$, respectively, except for the severity of brown spot in the trifloxystrobin $0.035 \mathrm{~g} / \mathrm{L}$ treatment, which was not significantly different from the untreated control (Table 3). Increasing the concentration of trifloxystrobin, but not azoxystrobin, significantly affected brown spot control (Table 3). Doubling the concentration of trifloxystrobin from $0.035 \mathrm{~g} / \mathrm{L}$ to $0.07 \mathrm{~g} / \mathrm{L}$ significantly reduced the severity of brown spot (Table 2). However, further doubling of the concentration from $0.07 \mathrm{~g} / \mathrm{L}$ to $0.15 \mathrm{~g} / \mathrm{L}$ failed to improve disease control (Table 3). Even at the highest trifloxystrobin concentration, the incidence of brown spot was still significantly higher than the industry standard and the two highest azoxystrobin treatments (Table 3).

Scale insect populations were not significantly different from the untreated control for all treatments except the trifloxystrobin $0.07 \mathrm{~g} / \mathrm{L}$ and $0.15 \mathrm{~g} / \mathrm{L}$ treatments (Table 3 ). The incidence and severity of scale significantly increased with increasing concentrations of trifloxystrobin (Table 3). Fruit aspect did not significantly influence brown spot (Table 3). Scale, however, was significantly worse on fruit harvested from the western side of the tree (Table 3).

\section{Experiment 3}

The incidence of brown spot was not significantly reduced by the industry standard treatment compared with the untreated control, despite being $\sim 25 \%$ lower (Table 4 ). However, the severity of brown spot was significantly reduced by $\sim 70 \%$ by all of the fungicide treatments compared with the untreated control (Table 4). All of the strobilurin fungicide treatments and captan had a significantly lower incidence and severity of brown spot compared with the untreated control (Table 4). The pyraclostrobin $0.8 \mathrm{~g} / \mathrm{L}$ and $1.2 \mathrm{~g} / \mathrm{L}$ treatments also had a significantly lower incidence and severity of brown spot compared with the industry standard (Table 4).

The incidence of scale insects was significantly higher for all of the fungicide treatments compared with the untreated control, except for the azoxystrobin $0.2 \mathrm{~g} / \mathrm{L}$ antiresistance and captan treatments (Table 4). All the fungicide treatments, except the industry standard, azoxystrobin $0.2 \mathrm{~g} / \mathrm{L}$ anti-resistance and captan treatments had significantly higher severities of scale insects compared with the untreated control. The only fungicide treatments found to be significantly different from the industry standard were the pyraclostrobin $0.8 \mathrm{~g} / \mathrm{L}$ and $1.2 \mathrm{~g} / \mathrm{L}$ treatments, which were found to have at least a $60 \%$ higher incidence of fruit with scale, and at least $30 \%$ more severe scale 
Table 3. Experiment 2 (2001-2002): effects of chemicals and canopy on the incidence and severity of citrus brown spot (caused by Alternaria alternata) and scale insects on cv. Murcott mandarin fruit ${ }^{\mathrm{A}}$

\begin{tabular}{|c|c|c|c|c|}
\hline \multirow{2}{*}{ Treatment } & \multicolumn{2}{|c|}{ Citrus brown spot } & \multicolumn{2}{|c|}{ Scale insects } \\
\hline & Incidence $^{\mathrm{B}}(\%)$ & Severity ${ }^{\mathrm{C}}$ (no./fruit) & Incidence $^{\mathrm{D}}(\%)$ & Severity $^{\mathrm{E}}(1-4)$ \\
\hline Untreated control & $92 \mathrm{a}$ & $8.3 \mathrm{a}$ & $37 \mathrm{~cd}$ & $1.5 \mathrm{~cd}$ \\
\hline Industry standard ${ }^{\mathrm{F}}$ & $10 \mathrm{e}$ & $0.4 \mathrm{~b}$ & $35 \mathrm{~cd}$ & $1.4 \mathrm{~cd}$ \\
\hline Azoxystrobin $0.2 \mathrm{~g} / \mathrm{L}$ & $18 \mathrm{de}$ & $0.7 \mathrm{~b}$ & $42 \mathrm{c}$ & $1.5 \mathrm{c}$ \\
\hline Azoxystrobin $0.4 \mathrm{~g} / \mathrm{L}$ & $11 \mathrm{e}$ & $0.5 \mathrm{~b}$ & $43 \mathrm{c}$ & $1.5 \mathrm{c}$ \\
\hline Azoxystrobin $0.6 \mathrm{~g} / \mathrm{L}$ & $12 \mathrm{e}$ & $0.4 \mathrm{~b}$ & $35 \mathrm{~cd}$ & $1.4 \mathrm{~cd}$ \\
\hline Trifloxystrobin $0.035 \mathrm{~g} / \mathrm{L}$ & $47 \mathrm{~b}$ & $5.2 \mathrm{a}$ & $41 \mathrm{c}$ & $1.5 \mathrm{c}$ \\
\hline Trifloxystrobin $0.07 \mathrm{~g} / \mathrm{L}$ & $40 \mathrm{bc}$ & $1.6 \mathrm{~b}$ & $65 \mathrm{~b}$ & $2.0 \mathrm{~b}$ \\
\hline Trifloxystrobin $0.15 \mathrm{~g} / \mathrm{L}$ & $27 \mathrm{~cd}$ & $1.0 \mathrm{~b}$ & $79 \mathrm{a}$ & $2.4 \mathrm{a}$ \\
\hline $\begin{array}{l}\text { Azoxystrobin } 0.2 \mathrm{~g} / \mathrm{L} \\
\text { anti-resistance } \mathrm{G}\end{array}$ & $13 \mathrm{e}$ & $0.5 \mathrm{~b}$ & $33 \mathrm{~cd}$ & $1.4 \mathrm{~cd}$ \\
\hline $\begin{array}{l}\text { Azoxystrobin } 0.4 \mathrm{~g} / \mathrm{L} \\
\text { anti-resistance }\end{array}$ & $8 \mathrm{e}$ & $0.3 \mathrm{~b}$ & $28 \mathrm{~cd}$ & $1.3 \mathrm{~d}$ \\
\hline $\begin{array}{l}\text { Trifloxystrobin } 0.07 \mathrm{~g} / \mathrm{L} \\
\text { anti-resistance }^{\mathrm{G}}\end{array}$ & $12 \mathrm{e}$ & $0.4 \mathrm{~b}$ & $39 \mathrm{~cd}$ & $1.5 \mathrm{~cd}$ \\
\hline $\begin{array}{l}\text { Trifloxystrobin } 0.15 \mathrm{~g} / \mathrm{L} \\
\text { anti-resistance }\end{array}$ & $10 \mathrm{e}$ & $0.4 \mathrm{~b}$ & $35 \mathrm{~cd}$ & $1.4 \mathrm{~cd}$ \\
\hline $\operatorname{LSD}(P=0.05)$ & 14 & 3.6 & 13 & 0.2 \\
\hline \multicolumn{5}{|l|}{ Canopy aspect } \\
\hline East & $26 \mathrm{a}$ & $1.9 \mathrm{a}$ & $41 \mathrm{~b}$ & $1.5 \mathrm{~b}$ \\
\hline West & $25 \mathrm{a}$ & $1.4 \mathrm{a}$ & $44 \mathrm{a}$ & $1.6 \mathrm{a}$ \\
\hline $\operatorname{LSD}(P=0.05)$ & - & - & 3 & 0.1 \\
\hline \multicolumn{5}{|c|}{$\begin{array}{l}{ }^{\mathrm{A}} \text { Mean values within columns followed by the same letter are not significantly different at } P=0.05(n=4) \text {. } \\
{ }^{\mathrm{B}} \text { Disease incidence rated as percentage of affected fruit. } \\
{ }^{\mathrm{C}} \text { Disease severity rated as counts of individual lesions. } \\
{ }^{\mathrm{D}} \text { Scale incidence rated as percentage fruit with } \geq 1 \% \text { surface area affected. } \\
{ }^{\mathrm{E}} \mathrm{Scale} \text { severity rated on a } 1-4 \text { scale based on a percentage surface area affected where } 1=0 \%, 2=1-25 \% \text {, } \\
3=26-50 \% 4=>50 \% \text {. } \\
\left.{ }^{\mathrm{F}} \text { Industry standard program }- \text { single application of copper oxychloride (Kocide at } 2 \mathrm{~g} / \mathrm{L}\right)+ \text { Oil (DC Tron at } \\
6 \mathrm{~mL} / \mathrm{L}) \text { followed by } 12 \mathrm{applications} \text { of Mancozeb DF }(2 \mathrm{~g} / \mathrm{L}) \text {. } \\
{ }^{\mathrm{G}} \text { Anti-resistance program - single application of copper oxychloride }(\text { Kocide at } 2 \mathrm{~g} / \mathrm{L})+\text { Oil (DC Tron at } \\
6 \mathrm{~mL} / \mathrm{L}) \text {, followed by two applications of a strobilurin, followed by } 11 \text { applications of Mancozeb DF }(2 \mathrm{~g} / \mathrm{L}) \text {. }\end{array}$} \\
\hline
\end{tabular}

infestation levels per fruit. Fruit aspect did not significantly influence brown spot (Table 4). Scale, however, was significantly worse on fruit harvested from the western side of the tree (Table 4).

\section{Discussion}

In each of three consecutive seasons, spray programs incorporating azoxystrobin were statistically as effective as the industry standard copper/mancozeb fungicides for the control of brown spot. Registration of this product for control of brown spot is, therefore, the most likely of all the strobilurins tested due the repeated demonstration of efficacy. Similar results have been demonstrated in the USA for brown spot, as well as the other citrus diseases melanose (caused by Diaporthe citri) (Raid et al. 1999), scab (caused by Elsinoe fawcettii), post-bloom fruit drop (caused by Colletotrichum acutatum) and greasy spot (caused by Mycosphaerella citri), (McMillan 1998; Raid et al. 1999). We also found that fruit treated with azoxystrobin, methoxycrylate, iprodione and chlorothalonil/pryrimthanil sustained significantly less rind damage than those treated with copper/mancozeb alone, as found in our concurrent studies evaluating chemicals for citrus black spot (caused by Guignardia citricarpa) control (Miles et al. 2004).

It should be noted that the highly specific mode of action of the strobilurins increases the potential for development of resistant pathogen individuals, and preventative measures need to be taken. Anti-resistance strategies are recommended by the Fungicide Resistance Action Committee (FRAC) to reduce the possibility of resistance developing, and include such rules as limiting strobilurin applications to one third of the total number of fungicide applications. Efficacy of the strobilurins was not compromised when they were integrated into an anti-resistance strategy. The use of an anti-resistance strategy is paramount to prolonging the useful life of the strobilurins, and the FRAC guidelines should be adhered to. Our data show that growers will not be disadvantaged by using anti-resistance regimes. 
Table 4. Experiment 3 (2002-2003): effects of chemicals and canopy aspect on the incidence and severity of citrus brown spot (caused by Alternaria alternata) and scale insects on cv. Nova mandarin fruit ${ }^{\mathrm{A}}$

\begin{tabular}{|c|c|c|c|c|}
\hline \multirow[t]{2}{*}{ Treatment } & \multicolumn{2}{|c|}{ Citrus brown spot } & \multicolumn{2}{|c|}{ Scale insects } \\
\hline & Incidence $^{\mathrm{B}}(\%)$ & Severity $^{\mathrm{C}}$ (no./fruit) & Incidence $^{\mathrm{D}}(\%)$ & Severity $^{\mathrm{E}}(1-4)$ \\
\hline Untreated control & $73 \mathrm{a}$ & $4.7 \mathrm{a}$ & $20.4 \mathrm{~d}$ & $1.2 \mathrm{c}$ \\
\hline Industry standard ${ }^{\mathrm{F}}$ & $54 \mathrm{ab}$ & $2.7 \mathrm{~b}$ & $42.1 \mathrm{bc}$ & $1.5 \mathrm{bc}$ \\
\hline $\begin{array}{l}\text { Azoxystrobin } 0.2 \mathrm{~g} / \mathrm{L} \\
\text { anti-resistance }^{\mathrm{G}}\end{array}$ & $40 \mathrm{bc}$ & $2.0 \mathrm{bc}$ & $36.8 \mathrm{bcd}$ & $1.4 \mathrm{bc}$ \\
\hline $\begin{array}{l}\text { Azoxystrobin } 0.4 \mathrm{~g} / \mathrm{L} \\
\text { anti-resistance }^{\mathrm{G}}\end{array}$ & $46 \mathrm{~b}$ & $1.2 \mathrm{bc}$ & $45.0 \mathrm{bc}$ & $1.6 \mathrm{~b}$ \\
\hline $\begin{array}{l}\text { Pyraclostrobin } 0.4 \mathrm{~g} / \mathrm{L} \\
\text { anti-resistance }^{\mathrm{G}}\end{array}$ & $33 \mathrm{bcd}$ & $1.2 \mathrm{bc}$ & $45.7 \mathrm{bc}$ & $1.6 \mathrm{~b}$ \\
\hline $\begin{array}{l}\text { Pyraclostrobin } 0.8 \mathrm{~g} / \mathrm{L} \\
\text { anti-resistance }^{\mathrm{G}}\end{array}$ & $35 \mathrm{bcd}$ & $1.4 \mathrm{bc}$ & $44.7 \mathrm{bc}$ & $1.6 \mathrm{~b}$ \\
\hline Pyraclostrobin $0.4 \mathrm{~g} / \mathrm{L}$ & $42 \mathrm{bc}$ & $1.2 \mathrm{bc}$ & $48.6 \mathrm{~b}$ & $1.6 \mathrm{~b}$ \\
\hline Pyraclostrobin $0.8 \mathrm{~g} / \mathrm{L}$ & $24 \mathrm{~cd}$ & $0.7 \mathrm{c}$ & $72.6 \mathrm{a}$ & $2.1 \mathrm{a}$ \\
\hline Pyraclostrobin $1.2 \mathrm{~g} / \mathrm{L}$ & $16 \mathrm{~d}$ & $0.4 \mathrm{c}$ & $68.5 \mathrm{a}$ & $2.0 \mathrm{a}$ \\
\hline Captan WG $1.25 \mathrm{~g} / \mathrm{L}$ & $45 \mathrm{bc}$ & $1.7 \mathrm{bc}$ & $30.7 \mathrm{~cd}$ & $1.4 \mathrm{bc}$ \\
\hline $\operatorname{LSD}(P=0.05)$ & 0.2 & 1.8 & 0.2 & 0.3 \\
\hline \multicolumn{5}{|l|}{ Canopy aspect } \\
\hline East & $42 \mathrm{a}$ & $1.6 \mathrm{a}$ & $42.3 \mathrm{~b}$ & $1.5 \mathrm{~b}$ \\
\hline West & $41 \mathrm{a}$ & $1.8 \mathrm{a}$ & $48.7 \mathrm{a}$ & $1.7 \mathrm{a}$ \\
\hline $\operatorname{LSD}(P=0.05)$ & - & - & 6.2 & 0.1 \\
\hline
\end{tabular}

\footnotetext{
${ }^{\mathrm{A}}$ Mean values within columns followed by the same letter are not significantly different at $P=0.05(n=4)$.

${ }^{\mathrm{B}}$ Disease incidence rated as percentage of affected fruit.

${ }^{\mathrm{C}}$ Disease severity rated as counts of individual lesions.

${ }^{\mathrm{D}}$ Scale incidence rated as percentage fruit with $\geq 1 \%$ surface area affected.

${ }^{\mathrm{E}}$ Scale severity rated on a $1-4$ scale based on a percentage surface area affected where $1=0 \%, 2=1-25 \%$, $3=26-50 \% 4=>50 \%$.

${ }_{\mathrm{F}}^{\mathrm{F}}$ Industry standard program - single application of copper oxychloride (Kocide at $2 \mathrm{~g} / \mathrm{L}$ ) + Oil (DC Tron at $6 \mathrm{~mL} / \mathrm{L})$ followed by 12 applications of Mancozeb DF $(2 \mathrm{~g} / \mathrm{L})$.

${ }^{\mathrm{G}}$ Anti-resistance program - single application of copper oxychloride (Kocide at $2 \mathrm{~g} / \mathrm{L}$ ) + Oil (DC Tron at

$6 \mathrm{~mL} / \mathrm{L})$, followed by two applications of a strobilurin, followed by 11 applications of Mancozeb DF (2 g/L).
}

The major scale insect species occurring in citrus include Aonidiella aurantii (California red scale), Unaspis citri (white louse scale), Chrysomphalus aonidum (circular black scale), Gascardia destructor (white wax scale), Cereplastes rubens (pink wax scale) and others (Smith and Papacek 1985). Numerous predatory wasp species are involved in controlling these pests including Paraceraptrocerus nyasicus, Aphytis lingnanensis, Comperiella bifasciata, Amblyseius lepidosaphes, Anicetus beneficus and several others (Smith and Papacek 1985). Our experiments showed that treatments containing azoxystrobin had no impact on scale insect severity and incidence compared with both the untreated control and industry standard treatments in experiment 2 . However, the severity and incidence of scale insects were found to be significantly higher than the untreated control for the higher anti-resistance rate in experiment 3 , but this treatment was not significantly different from the industry standard. Trifloxystrobin and pyraclostrobin on the other hand were found to affect scale insects. Both these strobilurins used alone at the two highest rates significantly increased scale severity and incidence compared with the industry standard. This suggests that these chemicals may be toxic or antagonistic to the predatory wasps used in the IPM of scales.

Trifloxystrobin applied alone at the lowest tested concentration was ineffective at controlling brown spot, and satisfactory control (not significantly lower than the industry standard) of disease severity was achieved only at two and four times this rate. Disease incidence was never satisfactorily reduced (not significantly lower than the industry standard) using trifloxystrobin alone. American reports have also shown that trifloxystrobin is less effective at controlling brown spot than azoxystrobin as well as a number of copper products (Raid and Timmer 1999). It is not surprising that our results showed trifloxystrobin to be less effective than azoxystrobin as both these products contain $50 \%$ a.i, yet the rates of product used were far less for trifloxystrobin, than for azoxystrobin. The rates of trifloxystrobin used in experiment 2 were originally determined from earlier experiments screening for control of citrus black spot, where trifloxystrobin at the rate of $0.07 \mathrm{~g} / \mathrm{L}$ was as effective as azoxystrobin at $0.4 \mathrm{~g} / \mathrm{L}$ (Miles et al. 2004). However, under the different orchard conditions and pathosystem in these experiments, trifloxystrobin at $0.15 \mathrm{~g} / \mathrm{L}$ could not 
satisfactorily reduce the incidence of brown spot. Increasing trifloxystrobin rates may improve brown spot control, but apart from the expense, it became apparent that increasing trifloxystrobin rates also increased the severity and incidence of scale. This effect is undesirable to the citrus industry and further tests were not conducted. Pyraclostrobin had a similar effect on scale insects, with both severity and incidence of scale at the two highest rates being significantly higher than the untreated control and industry standard. Brown spot control by pyraclostrobin was satisfactory, however, and thus is potentially of use to the citrus industry.

Acibenzolar alone was ineffective at controlling brown spot, and the only instance where tank mixing acibenzolar with another chemical was effective was when mixed with azoxystrobin. Adding acibenzolar to azoxystrobin significantly decreased the incidence of brown spot compared with using azoxystrobin alone. However, neither of these treatments was significantly different from the industry standard. Further testing of acibenzolar was not pursued, as it seemed unlikely that acibenzolar could offer any commercial brown spot control. This is in contrast to our citrus black spot experiments, where acibenzolar reduced the incidence of black spot (50\% reduction compared with the untreated control), but not as much as the industry standard copper/mancozeb or the strobilurins $(60 \%$ to over $90 \%$ reductions compared with the untreated control) (Miles et al. 2004). The difference is most likely due to the differences in epidemiology between A. alternata and G. citricarpa. The latter undergoes a long latent phase after infection (Kotze 1981) as an asymptomatic knot of mycelium under the fruit cuticle (Brodrick and Rabie 1970). Once fruit reach full maturity, this latent infection will develop into a typical black spot lesion (Calavan 1960). During the latent phase, the fungus is in close contact with the products of the host's biochemistry, making it more susceptible to host defence compounds such as citral (Rodov et al. 1995), citrinol, narigin, hesperidin (Arimoto et al. 1986), osthol, auraptene, coumarin, anoxycoumarin (Ben-Yehoshua et al. 1988) and scoparone (Kim et al. 1991), which may be stimulated by acibenzolar. A. alternata, however, will be less susceptible to such compounds, as it kills host cells prior to colonisation, therefore reducing its contact with active host biochemistry. Willingham et al. (2002) also found that A. alternata, causing leaf spot of passionfruit, was poorly controlled with acibenzolar, compared with Cladosporium oxysporum (the cause of scab) which, like G. citricarpa, is readily exposed to host biochemistry.

Of the other products tested, methoxycrylate was an effective fungicide, even though only eight applications were applied (compared with 16 applications of the other products). Greatly superior performance of this product is an unlikely explanation of its ability to control brown spot without applying the chemical beyond the $8^{\text {th }}$ application.
It is more likely that the observations of Timmer et al. (2000) that fruit are resistant to brown spot when greater than $\sim 5 \mathrm{~cm}$ in diameter are correct. Further studies of susceptibility of fruit to brown spot under Australian conditions are required to resolve this issue. If fruit can be shown to be resistant at this time, the potential exists to greatly reduce the amount of fungicide being applied to Queensland citrus under high disease pressure conditions. Further testing of methoxycrylate was abandoned due to manufacturer withdrawal of the product from commercial production.

Iprodione was effective for brown spot control, and its effectiveness has been shown in South Africa (Swart et al. 1998), Israel and the USA (Solel et al. 1997). However, iprodione is registered for non-bearing citrus only in Australia, and despite its efficacy and reported nil toxicity to the IPM insect Amblyseius victoriensis (James and Rayner 1995), it cannot be used on fruitbearing trees. Chlorothalonil/pyrimthanil, although effective in controlling brown spot and not causing significant rind damage, was withdrawn from the experiments due to unlikely manufacturer support for registration.

Captan is a very promising fungicide for brown spot control as it not only provided protection as effective as that of the industry standard, but also showed no increase in the severity and incidence of scale. In our other evaluation experiments it has also shown low toxicity to the citrus integrated pest management insect Amblyseius victoriensis (Miles et al. 2004). However, the product was tested in only one season and experiments with this product should be repeated.

The significantly increased scale insects on fruit harvested from the western side of the tree canopy compared with the eastern is likely to be related to the higher temperatures on the western aspect. The higher temperatures are likely to increase the development of the scale insects and hinder the development of the ectoparasitoids that feed upon them (D. Papacek and D. Smith, personal communications). $\mathrm{Yu}$ and Luck (1988) reported that the duration of developmental stages of California red scale (A. aurantii) that are susceptible to parasitism by the ectoparasitic wasp A. melinus decreases with increasing temperature, and Kfir and Luck (1984) reported that development of the ectoparasitoid A. chrysomphali is completely halted by temperatures above $32^{\circ} \mathrm{C}$, especially at low humidity.

The significant increase in rind damage on the eastern aspect of the canopy is likely to be related to the cooler temperature of the eastern aspect. Cool temperatures reduce evaporation, prolonging the presence of fungicide solutions and the potential for chemical injury. Evapo-transpiration is also reduced at cooler temperatures, resulting in relatively more turgid fruit, which are more susceptible to physical injury. 
Our experiments have demonstrated the effectiveness of the strobilurin fungicides as a new fungicide group to incorporate into spray programs for managing brown spot in Australia. The proposed anti-resistance regimes not only reduce the risk of resistance development, but also promote the longevity of beneficial insects by reducing the input of mancozeb. Reducing the use of mancozeb and copper also has the potential to reduce fruit damage and lower inputs of these chemicals into the environment. The introduction of additional fungicide products to the Australian citrus industry will contribute to the production of higher quality citrus fruit, and the sustainability of the industry.

\section{Acknowledgements}

The authors gratefully acknowledge the financial support of the Australian citrus growers through Horticulture Australia Limited, and of the Department of Primary Industries - Horticulture (Queensland). Further thanks go to Sunstate Orchards for use of their Tiaro orchards for our experiments. Dan Papacek of Bugs For Bugs and Dan Smith and Chris Freebairn of the Department of Primary Industries (Queensland) provided entomological expertise. We also thank Vivienne Doogan for advice on statistical analysis, and the members of the Central Burnett Horticultural Committee for their advice and encouragement. Technical assistance was provided by Dean Beasley, Jan Dean, Fiona Giblin, Claire Purcell, Dominic Hooghuis and Luke Smith.

\section{References}

Agostini JP, Bushong PM, Timmer LW (2003) Greenhouse evaluation of products that induce host resistance for control of scab, melanose, and Alternaria brown spot of citrus. Plant Disease 87, 69-74.

Arimoto Y, Homma Y, Misato T (1986) Studies on citrus melanose and citrus stem end rot by Diaporthe citri (Faw) Wolf. Part 4 Antifungal substance in melanose spot. Annals Phytopathology Society of Japan 52, 39-46.

Becker WF, von Jagow G, Anke T, Steglich W (1981) Oudemansin, strobilurin A, strobilurin B and myxothiazol: new inhibitors of the $\mathrm{bc}_{1}$ segment of the respiratory chain within an $E$ - $\beta$-methoxyacrylate system as common structural element. FEBS Letters 132, 329-333. doi: 10.1016/0014-5793(81)81190-8

Ben-Yehoshua S, Shapiro S, Kim JJ, Sharoni J, Carmeli S, Kashman Y (1988) Resistance of fruit to pathogens and its enhancement by curing. In 'Proceedings of the sixth international citrus congress'. (Eds R Goren, K Mendel) pp. 1371-1379. (Balaban Publishers: Tel Aviv)

Brodrick HT, Rabie CJ (1970) Light and temperature effects on symptom development and sporulation of Guignardia citricarpa Kiely, on Citrus sinensis (Linn) Osbeck. Phytophylactica 2, $157-164$.

Calavan EC (1960) Black spot of citrus. The California Citrograph November, 4-24.

Cobb NA (1903) Letters on the diseases of plants - Alternaria of the citrus tribe. Agricultural Gazette of New South Wales 14, 955-986.
Friedrich L, Lawton K, Ruess W, Masner P, Specker N, et al. (1996) A benzothiadiazole derivative induces systemic acquired resistance in tobacco. The Plant Journal 10, 61-70. doi: 10.1046/J.1365-313X.1996.10010061.X

Godwin JR, Young JE, Hart CA (1994) ICIA 5504: effects on development of cereal pathogens. In 'Proceedings of the Brighton crop protection conference'. pp. 259-264. (British Crop Protection Council: Brighton, UK)

Hutton DG, Mayers PE (1988) Brown spot of Murcott tangor caused by Alternaria alternata in Queensland. Australasian Plant Pathology 17, 69-73.

James DG, Rayner M (1995) Toxicity of viticultural pesticides to the predatory mites Amblyseius victoriensis and Typhlodromus doreenae. Plant Protection Quarterly 10, 99-102.

Kfir R, Luck RF (1984) Effects of temperature and relative humidity on developmental rate and adult life span of three Aphytis species (Hymenoptera: Aphelinidae) parasitising California red scale Journal of Applied Entomology 97, 314-320.

Kim JJ, Ben-Yehoshua S, Shapiro B, Henis Y, Carmeli S (1991) Accumulation of scoparone in heat-treated lemon fruit inoculated with Penicillium digitatum. Plant Physiology 97, 880-885.

Kohmoto K, Akimitsu K, Otani H (1991) Correlation of resistance and susceptibility of citrus to Alternaria alternata with sensitivity to host-specific toxins. Phytopathology 81, 719-722.

Kotze JM (1981) Epidemiology and control of citrus black spot in South Africa. Plant Disease 65, 945-955.

Lawton KA, Friedrich L, Hunt M, Weymann K, Delaney T, Kessmann H, Staub T, Ryals J (1996) Benzothiadiazole induces disease resistance in Arabidopsis by activation of the systemic acquired resistance signal transduction pathway. The Plant Journal 10, 71-82. doi: 10.1046/J.1365-313X.1996. 10010071.X

McMillan RT (1998) Citrus, tropical and miscellaneous crop reports. Fungicide and Nematicide Tests 53 (489), 391.

Miles AK, Willingham SL, Cooke AW (2004) Field evaluation of strobilurins and a plant activator for the control of citrus black spot. Australasian Plant Pathology (in press).

Nishimura S, Kohmoto K (1983) Host-specific toxins and chemical structures from Alternaria species. Annual Review of Phytopathology 21, 87-116. doi: 10.1146/ANNUREV.PY.21. 090183.000511

Pegg KG (1966) Studies of a strain of Alternaria citri Pierce, the causal organism of brown spot of Emperor mandarin. Queensland Journal of Agricultural and Animal Sciences 23, 15-28.

Persley D (1993) 'Diseases of fruit crops.' pp. 37-38. (Queensland Department of Primary Industries, Queensland Government Publishing Services: Brisbane)

Raid RN, Timmer LW, Zitko SE (1999) Citrus, tropical and miscellaneous crop reports. Fungicide and Nematicide Tests 54, 553-556.

Raid RN, Timmer LW (1999) Citrus, tropical and miscellaneous crop reports. Fungicide and Nematicide Tests 55, 570.

Rodov V, Ben-Yehoshua S, Fang DQ, Jin Kim J, Ashkenazi R (1995) Preformed antifungal compounds of lemon fruit: citral and its relation to disease resistance. Journal of Agricultural and Food Chemistry 43, 1057-1061.

Sauter H, Ammermann E, Roehl F (1996) Strobilurins - from natural products to a new class of fungicides. In 'Crop protection agents from nature'. (Ed. LG Copping) pp. 50-81. (The Royal Society of Chemistry, Thomas Graham House: Cambridge, UK)

Schutte GC, Beeton KV, Kotze JM (1997) Rind stippling on valencia oranges by copper fungicides used for control of citrus black spot in South Africa. Plant Disease 81, 851-854. 
Smith D, Papacek DF (1985) Integrated pest management in Queensland citrus. Queensland Agricultural Journal September-October, 249-259.

Smith D, Papacek DF (1991) Studies of the predatory mite Amblyseius victoriensis (Acarina: Phytoseiidae) in citrus orchards of south-east Queensland: control of Tegolophus australis and Phyllocoptruta oleivora (Acarina: Eriophyidae), effect of pesticides, alternative host plants and augmentative release. Experimental \& Applied Acarology 12, 195-217.

Solel Z, Oren Y, Kimchi M (1997) Control of Alternaria brown spot of Minneola tangelo with fungicides. Crop Protection (Guildford, Surrey) 16, 659-664. doi: 10.1016/S0261-2194 (97)00042-2

Swart SH, Wingfield MJ, Swart WJ, Schutte GC (1998) Chemical control of Alternaria brown spot on Minneola tangelo in South Africa. The Annals of Applied Biology 133, 17-30.

Tally A, Oostendorp M, Lawton K, Staub T, Bassi B (1999) Commercial development of elicitors of induced resistance to pathogens. In 'Induced plant defenses against pathogens and herbivores'. (Eds A Agawal, S Tuzun, E Bent) pp. 357-369. (APS Press: St Paul)
Timmer LW, Darhower HM, Zitko SE, Peever TL, Ibanez AM, Bushong PM (2000) Environmental factors affecting the severity of alternaria brown spot of citrus and their potential use in timing fungicide applications. Plant Disease 84, 638-643.

Timmer LW, Solel Z, Gottwald TR, Ibanez AM, Zitko SE (1998) Environmental factors affecting production, release, and field populations of conidia of Alternaria alternata, the cause of brown spot of citrus. Phytopathology 88, 1218-1223.

Willingham SL, Pegg KG, Langdon PWB, Cooke AW, Peasley D, Mclennan R (2002) Combinations of strobilurin and acibenzolar (Bion) to reduce scab on passionfruit caused by Cladosporium oxysporum. Australasian Plant Pathology 31, 333-336. doi: 10.1071/AP02036

Yu DS, Luck RF (1988) Temperature-dependent size and development of California red scale (Homoptera: Diaspididae) and its effect on host availability for the ectoparasitoid, Aphytis melinus DeBach (Hymenoptera: Aphelinidae). Environmental Entomology 17, 154-161.

Received 19 April 2004, accepted 5 August 2004 